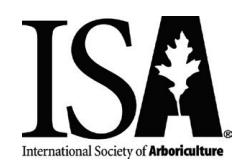

\title{
Long-Term Fluctuations in Water Status and Crown Dieback of Plains Cottonwood Trees
}

\author{
William R. Jacobi, Ronda D. Koski, and Betsy A. Goodrich
}

\begin{abstract}
Plains cottonwood trees (Populus deltoides subsp. monilifera (Aiton) Eckenw.) occur in riparian and urban areas in semi-arid regions of western United States. The amount of water necessary to maintain healthy trees while reducing water use are management objectives along the High Line Canal in Denver, Colorado, U.S. Canal-flow days, soil moisture, precipitation, cottonwood predawn leaf water potentials ( $\psi \mathrm{pd})$ and crown dieback were measured annually from 1997-2008. Five key findings were: 1) percent soil moisture did not correlate with $\psi \mathrm{pd}, 2)$ trees became moderately water-stressed ( $\psi \mathrm{pd}<-0.3 \mathrm{MPa}$ ) and severely water-stressed $(<-0.5 \mathrm{MPa}) 45$ and 51 days after canal flow ended, respectively, 3) $\psi$ pd of water-stressed trees increased 24-48 hours after water was added, 4) only $22 \%$ of rain events of $25 \mathrm{~mm}$ relieved stressed conditions for seven days, and 5) yearly average autumn and growing season $\psi$ pd correlated with autumn crown dieback at low soil moisture sites (few canal-flow days), but not at moderate or high sites (more canalflow days). Trees with $\psi$ pd $>-0.30 \mathrm{MPa}$ generally had low crown dieback, whereas trees with $\psi$ pd $<-0.50$ MPa exhibited moderate or severe crown dieback. Plains cottonwoods are relatively resilient to single-year drought, and moderately stressed trees may recover and can withstand $25 \%-40 \%$ crown dieback if water is available the following year for $>14$ days. Irrigation timing and the frequency needed to minimize cottonwood future crown dieback can be obtained from autumn and growing season predawn leaf water potentials.

Key Words. Colorado; Cottonwood; Crown Dieback; Mortality; Populus deltoides; Semi-Arid; Water Potential; Water Stress.
\end{abstract}

In semi-arid regions of the western United States, plains cottonwood trees (Populus deltoides subsp. monilifera (Aiton) Eckenw.) occur naturally in riparian areas, floodplains, along irrigation watercourses in rural areas, and are planted in urban landscapes. Although cottonwood trees are common shade trees in moderately dry environments and can tolerate short-term periods of drought, they need periodic sources of water to avoid mortality (Rood and Mahoney 1995; Scott et al. 1999; Amlin and Rood 2003; Rood et al. 2003; Fichot et al. 2015). Landowners residing in urban areas with limited rainfall have a desire to preserve the health of these trees for their aesthetic and ecological values, but the amount of water necessary to maintain tree health is not always known. Defining this relationship can help sustain limited resources. A unique opportunity to study the relationships between cottonwood crown health and soil moisture in an urban environment occurred as part of a long-term study of cottonwoods along an agricultural irrigation canal passing through the metropolitan area of Denver, Colorado, U.S. The canal was managed by Denver Water, the provider of water to residents, businesses, and communities of the Denver metropolitan area. Completed in 1883, the $109 \mathrm{~km}$ High Line Canal (HLC) was designed to deliver water to the dry plains northeast of Denver (Skari 2003). Changing land-use practices from agriculture to urban development reduced the need for many irrigation canals along the urban Front Range of Colorado, including the HLC. Many large diameter $(80-100 \mathrm{~cm})$ cottonwood trees were common along the banks of the canal, and urban park agencies and municipalities responsible for adjacent land management wanted to maintain these large shade trees as components of the urban forest. Following decreases in canal use for water transport, this study was initiated in 1997 to determine the minimum water needs of the cottonwood trees growing along the HLC to minimize branch dieback and mortality.

Previous research on the water requirements of various species of cottonwood (Populus spp.) 
and their tolerance to water stress over long periods is well summarized by Rood et al. (2003) and Fichot et al. (2015). Cottonwood tree roots are found in the water table or in the saturated zone above the surface of the water table; trees growing on shallow groundwater sites exhibit shallow, laterally spreading root structures in close association with the saturated zone (Horton et al. 2001; Cooper et al. 2003; Horton et al. 2003). Under conditions of prolonged, belownormal precipitation (i.e., drought), shallowrooted plains cottonwood trees exhibit greater water stress (more negative leaf water potentials) than more deeply rooted trees (Scott et al.1999). Cottonwood trees growing on alluvial sites of coarse-textured sand with shallow groundwater are vulnerable to water-table declines due, in part, to limited soil volume for tree roots above the water table. Cottonwood trees subjected to rapid water-table decline are often unable to adjust to the water stress induced by the sudden reduced availability of water (Scott et al.1999; Cooper et al. 2003; Williams and Cooper 2005).

In most trees, water stress begins to develop when predawn leaf water potentials $(\psi \mathrm{pd})$ are in the range of -0.20 to $-0.30 \mathrm{MPa}$ (Kramer and Kozlowski 1979). Cottonwoods may respond to water stress with both physiological (decreased stomatal conductance and reduced shoot/leaf water potential) and morphological (changes in leaf attributes, reduced growth, or leaf mortality) alterations (Schulte et al. 1987; Cooper et al. 2003; Rood et al. 2003). Severe water stress can induce embolism or cavitation in xylem vessels, leading to leaf, branch, or tree mortality. Eastern cottonwoods (Populus deltoides subsp. deltoides W. Bartram ex Marshall) are one of the most vulnerable tree species to drought-induced xylem dysfunction due to cavitation (Tyree et al. 1994; Scott et al. 1999; Fichot et al. 2015). In one-year-old detached stem segments of eastern cottonwoods, $20 \%$ cavitation began when xylem water potential reached approximately $-0.3 \mathrm{MPa} ; 50 \%$ cavitation at $-0.7 \mathrm{MPa}$, and complete cavitation occurred at approximately -2.0 to $-2.5 \mathrm{MPa}$ (Tyree et al. 1994). Branch death from cavitation is assumed to occur from the stressful midday (maximum) xylem water potentials ( $\psi \mathrm{md}$ ) that occur over several days or weeks and induce hydraulic fail- ure (Cooper et al. 2003; Fichot et al. 2015). In the field, however, plains cottonwoods live through periods of hot and dry weather with midday water potentials ( $\psi \mathrm{md}$ ) lower than that reported to cause $80 \%$ cavitation in laboratory studies of eastern cottonwoods (Tyree et al. 1994), and nightly recovery when transpiration ceases can be observed by measuring upd (Cooper et al. 2003).

While upd measurements do not represent the most stressful time of the day for trees, predawn water potentials are easier than midday water potential ( $\psi \mathrm{md}$ ) measurements to consistently obtain and relate to tree dieback. Predawn water potentials ( $\psi \mathrm{pd}$ ) are also preferred over $\psi$ md since they are not as subject to fluctuations in environmental conditions, such as irradiance and air temperature, especially when trees are extremely stressed (Jones 1990; Cooper et al. 2003; Williams and Cooper 2005; Fichot et al. 2015). Relationships between predawn and midday leaf $\psi$ can vary; daily decreases in $\psi$ pd have been correlated with increases in $\psi \mathrm{md}$ due to stomatal closures and branch dieback (Cooper et al. 2003), but predawn, mid-day leaf, and midday stem $\psi$ can also be highly correlated with one another (Williams and Araujo 2002).

There are limited published relationships between $u p d$ of plains cottonwood trees and the associated amount of crown dieback and mortality of mature trees in the field. During an experimental water-table drawdown along a Colorado river, the $\psi \mathrm{pd}$ of plains cottonwood trees eventually reached -0.4 to $-0.8 \mathrm{MPa}$, resulting in leaf and twig death (Cooper et al. 2003). This rapid leaf death indicates the sensitivity of cottonwoods to a rapid reduction in groundwater availability, but also that some recovery can occur following the addition of water (Cooper et al. 2003). Where surface irrigation was experimentally applied after water-table drawdown, trees recovered from water stress as measured by predawn xylem $\psi$ (Cooper et al. 2003). Because of the desire to preserve plains cottonwood trees along the High Line Canal while limiting water use in the canal and the few field studies on the vulnerability of plains cottonwoods to crown dieback in the arid west, researchers initiated the current long-term study along the High Line Canal in Denver, Colorado. 


\section{OBJECTIVES}

This study was initiated to quantify the amount of water (i.e., canal-flow days or amount of precipitation) necessary to maintain plains cottonwood tree health (minimal crown dieback) when canal water flow days were reduced in the HLC in Denver, Colorado. The study attempted to provide answers to the following five questions:

1. Can percent soil moisture predict tree predawn leaf water potential?

2. How long does it take for trees to become water-stressed when water is withheld?

3. How rapidly do moderately to severely water-stressed trees recover after water is provided?

4. Do summer precipitation events reduce tree water stress?

5. Can predawn tree water potentials predict future crown dieback?

\section{MATERIALS AND METHODS}

Fifteen study sites were established along the HLC in the Denver, Colorado, metro area in 1997, with eight more sites added in 1999 (Table 1; Figure 1). The study area without irrigation was a typical semi-desert grassland and shrubland, with an average elevation of 1,610 $\mathrm{m}$ and where cottonwood trees only occurred along waterways. The soils in the Sand Creek, Toll Gate Creek, and Cherry Creek canal sections were classified as loamy sand, silt loam, and loamy sand, respectively (Figure 1). The soil moisture depends on both winter and summer precipitation, where winter precipitation (OctoberApril) averaged $229 \mathrm{~mm}$ and average summer precipitation (May-September) averaged 173 $\mathrm{mm}$ for a yearly average of $402 \mathrm{~mm}$ (based on 30 -year averages from the National Oceanic and Atmospheric Administration, Denver Stapleton, Meteorological Station, \#0522220). Thirty-year average winter temperature is $4.2^{\circ} \mathrm{C}$, and average summer temperature is $19.5^{\circ} \mathrm{C}$, with an average summer maximum of $27.0^{\circ} \mathrm{C}$. Sites were selected in 1997, and were located 71 to $103 \mathrm{~km}$ downstream from the beginning of the canal (Table 1; Figure 1). At each site, three to seven plains cottonwood trees, growing within 0.5 to
$3.0 \mathrm{~m}$ of the canal edge and within $30.0 \mathrm{~m}$ of each other, were tagged for repeated observations and data collection. Each tree had branches within 3 to $4 \mathrm{~m}$ of the ground, so leaves could easily be collected for water potential readings. Tree diameter at breast height $(\mathrm{DBH}, 1.4 \mathrm{~m}$ from the ground level) was measured in centimeters with a diameter tape; height was measured in meters with an inclinometer or laser. Mean tree $\mathrm{DBH}$ was $63.6 \mathrm{~cm}(\mathrm{SE}=2.08)$, and the mean height was $15.5 \mathrm{~m}(\mathrm{SE}=0.83)$ (Table 1). Soil moisture, $\psi \mathrm{pd}$, and percent crown dieback were collected yearly at some sites, while sporadically at others, from 1997 to 2008 (Table 1). Percent crown dieback was defined as the percent of the tree crown with recent branch death indicated by failure to leaf out or premature defoliation. Percent crown dieback was evaluated by the same researcher in the spring (MayJune) and in autumn (September) of each year.

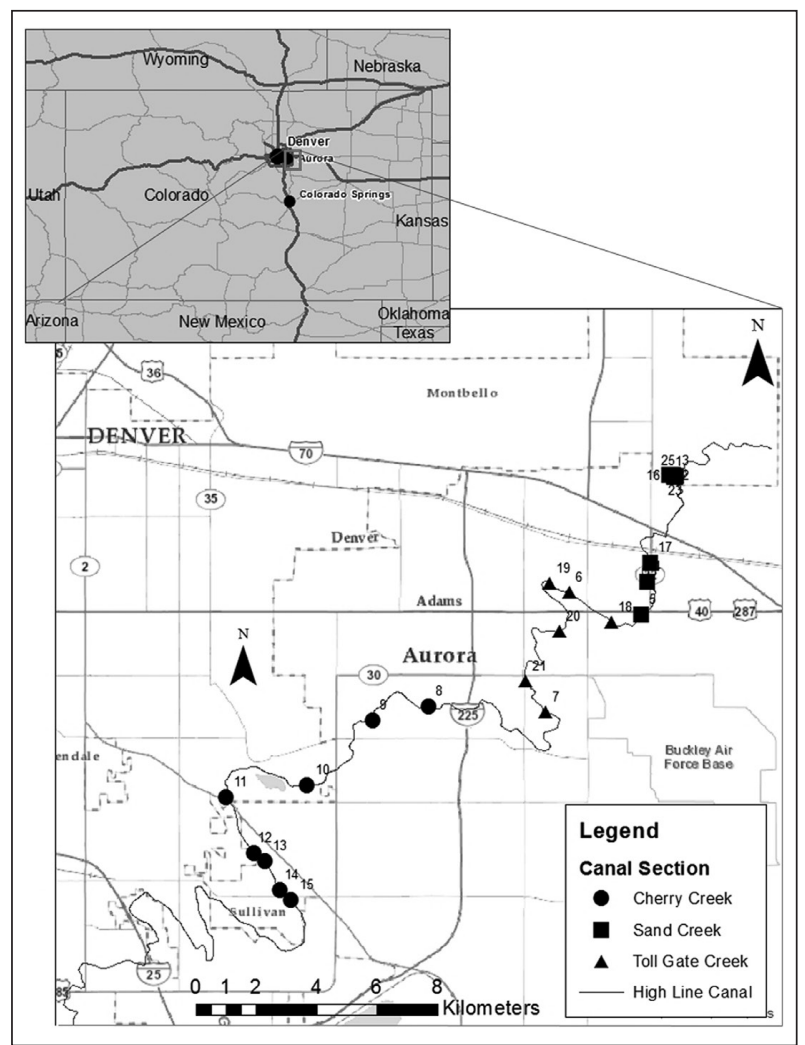

Figure 1. Map of plains cottonwood study sites, site numbers, and canal sections along High Line Canal, Denver, Colorado, U.S. (1997-2008). 
Table 1. Distance from beginning of canal, mean cottonwood tree size attributes, sample size ( $n=$ number of trees), and data collection years for each study site (within canal section) along the High Line Canal, Denver, Colorado, U.S. (19972008). Hyphen (-) = data not collected.

\begin{tabular}{|c|c|c|c|c|c|c|c|c|}
\hline \multirow[t]{2}{*}{ Canal section } & \multirow[t]{2}{*}{ Site \# } & \multirow{2}{*}{$\begin{array}{l}\text { Distance from canal } \\
\text { beginning }(\mathrm{km})\end{array}$} & \multirow{2}{*}{$\begin{array}{l}\text { Tree DBH } \\
(\mathrm{cm})\end{array}$} & \multirow{2}{*}{$\begin{array}{l}\text { Tree height } \\
(\mathrm{m})\end{array}$} & \multirow{2}{*}{$\begin{array}{l}\text { Trees } \\
(\mathrm{n})\end{array}$} & \multicolumn{3}{|l|}{ Years of data collection } \\
\hline & & & & & & $\begin{array}{l}\text { Predawn leaf water } \\
\text { potential ( } \psi \mathrm{pd})\end{array}$ & $\begin{array}{l}\text { Soil } \\
\text { moisture }\end{array}$ & $\begin{array}{l}\text { Depth to } \\
\text { water table }\end{array}$ \\
\hline \multirow[t]{8}{*}{ Cherry Creek } & 8 & 84.3 & 68.8 & 14.7 & 5 & 1997-1999, 2004-2008 & - & - \\
\hline & 9 & 81.3 & 34.5 & 13.2 & 5 & 1997-1999, 2004-2008 & - & - \\
\hline & 10 & 78.4 & 77.1 & 22.2 & 5 & 1997-1999, 2004-2008 & - & - \\
\hline & 11 & 75.5 & 48.0 & 15.4 & 5 & 1997-1999, 2004-2008 & - & - \\
\hline & 12 & 75.2 & 89.5 & 18.6 & 5 & 1997-1999, 2004-2008 & - & - \\
\hline & 13 & 74.4 & 29.2 & 12.5 & 5 & 1997-1999, 2004-2008 & - & - \\
\hline & 14 & 74.0 & 77.3 & 16.8 & 5 & 1997-1999, 2004-2008 & - & - \\
\hline & 15 & 72.0 & 40.4 & 12.9 & 5 & $1997-1999$ & - & - \\
\hline \multirow[t]{6}{*}{ Toll Gate Creek } & 6 & 95.2 & 83.9 & 20.6 & 5 & $1997-2008$ & 1999-2003 & $2001-2003$ \\
\hline & 7 & 89.0 & 24.7 & 9.8 & 5 & 1997-2001, 2004-2008 & - & - \\
\hline & 18 & 96.0 & 116.7 & 17.0 & 3 & 1999-2006 & - & - \\
\hline & 19 & 94.4 & 86.1 & 19.0 & 3 & 1999-2008 & $2002-2003$ & \\
\hline & 20 & 92.8 & 28.6 & 11.9 & 3 & 1999-2008 & 1999-2003 & 2001-2003 \\
\hline & 21 & 89.8 & 23.2 & 10.0 & 3 & 1999-2001 & - & - \\
\hline \multirow[t]{10}{*}{ Sand Creek } & 1 & 102.4 & 113.9 & 16.9 & 5 & $1997-1999$ & - & - \\
\hline & $2 \mathrm{E}$ & 102.0 & 103.1 & 20.7 & 7 & 1997-2003, 2006-2008 & $2001-2003$ & \\
\hline & $2 \mathrm{~W}$ & 102.0 & 103.1 & 20.7 & 7 & & 1999-2003 & \\
\hline & 3 & 102.1 & 35.0 & 14.3 & 5 & 1997-2003 & - & - \\
\hline & 4 & 98.6 & 85.4 & 21.8 & 5 & 1997-2002 & - & - \\
\hline & 5 & 98.2 & 135.1 & 17.4 & 5 & 1997-2001 & - & - \\
\hline & 16 & 102.1 & 22.0 & 8.8 & 3 & 1999-2003 & $2001-2003$ & - \\
\hline & 17 & 99.2 & 39.0 & 14.7 & 3 & $1999-2003$ & 1999-2003 & $2001-2003$ \\
\hline & 23 & 102.1 & 23.6 & 9.2 & 3 & 2001-2003, 2007-2008 & $2001-2003$ & $3-$ \\
\hline & 25 & 102.1 & 38.5 & 14.4 & 3 & 2001-2003, 2007-2008 & $2001-2003$ & $3-$ \\
\hline
\end{tabular}

\section{Soil Moisture and Root Distribution}

Soil moisture was monitored to compare to $\psi$ pd as a measure of tree water status. Soil moisture was monitored at four sites $(2 \mathrm{~W}, 6,17,20)$ in August 1999, and July through September 2000-2003, and at five more sites $(2 \mathrm{E}, 16,19,23,25)$ from $2001-$ 2003 with a neutron probe (Troxler 4300, Troxler Electronic Laboratories, Inc., Research Triangle Park, North Carolina, U.S.). At each of the soil moisture monitoring sites, three aluminum soil access tubes were placed in the canal bank in two sets, $5 \mathrm{~m}$ apart, at 1.0, 7.6, and $15.2 \mathrm{~m}$ perpendicular and away from the edge of the canal. Groundwater observation wells were also placed 1.0, 7.6, and $15.2 \mathrm{~m}$ perpendicular to the edge of the canal at sites 2, 6, 17, and 20. Percent soil moisture was monitored every two weeks at depths of $0.3,0.9$, $1.5,2.1$, and $2.7 \mathrm{~m}$. Depth to groundwater was measured the same date when soil moisture data were collected at groundwater wells at sites 2, 6, 17 , and 20. The canal bottom and normal highwater depth was surveyed at each site with a transit to determine and record their relationship to the depths percent soil moisture. These depth data were then used to determine what soil moisture readings would be expected to be influenced by canal flow. Canal flow is presented as the number of days of flow based on in-canal staff gages.

Root distribution was measured in 2001 on one large cottonwood $(78 \mathrm{~cm} \mathrm{DBH})$ growing on the canal bank one meter from the canal edge along the Sand Creek canal section where there was no surrounding urban development. A 2 $\mathrm{m}$ wide $\times 2 \mathrm{~m}$ deep trench, located two meters from the tree and perpendicular to the canal, was excavated from the center of the canal to five meters away from the edge of the canal. All roots were counted on the trench surface in $0.6 \mathrm{~m}$ wide $\times 1.8 \mathrm{~m}$ deep sections and placed into diameter classes of small $(0.001-0.3 \mathrm{~cm})$, medium $(0.31-2.5 \mathrm{~cm})$, and large $(>2.5 \mathrm{~cm})$.

\section{Leaf Water Potential Measurements}

Predawn (10 pm-2 am) leaf water potentials ( $\psi$ pd) were obtained from two leaves, each from a different branch using a pressure chamber (PMS Instrument Company, Corvallis, Oregon, U.S.). Water potentials were obtained every two weeks, until mid- to late-summer when $\psi$ pd dropped below $-0.3 \mathrm{MPa}$, and then 4 pd were obtained 
weekly. Yearly upd were first obtained within a few weeks of leaf expansion in the spring (20 May - 10 June), and ended in late-summer before leaf abscission zone formation (03-15 September). During simulated canal runs, additional upd data were collected. Researchers developed three $\psi$ pd ranges to represent none to mild water stress $(-0.10$ to $-0.29 \mathrm{MPa})$, moderate water stress $(-0.30$ to $-0.50 \mathrm{MPa})$, and severely stressed $(<-0.5 \mathrm{MPa})$. Ranges were based on published $\psi$ of cavitation events (Tyree et al. 1994; Cooper et al. 2003), and personal knowledge from collecting 4 pd and crown dieback measurements for ten consecutive years. Midday leaf water potentials ( $\psi \mathrm{md}$ ) were collected three times during the summer of 1999 within 12 hours of the $\psi$ pd for comparison, but due to high variability between measurements within a tree and across days, all analyses were conducted using only $\psi \mathrm{pd}$.

\section{Water Stress Recovery}

Simulated canal runs were conducted 29 July to 02 August 2002 at site 2,13-14 August at site 19, and 04-15 August 2003 at sites 2, 6, and 17, to determine how fast water-stressed trees would recover (measured by $\psi \mathrm{pd}$ ). Canal-run tests also determined how long reduced-water stress in cottonwoods would be maintained following the canal run. Basins were created at the sites by putting temporary dams in the canal. Water was trucked in or obtained from nearby fire hydrants on six different days to provide $0.3 \mathrm{~m}$ of water in the canal each time water was added. At site 2, the basin was $87.2 \mathrm{~m} \times 3 \mathrm{~m} \times$ $0.3 \mathrm{~m}$ deep; at site 6 , the basin was $90 \mathrm{~m} \times 3 \mathrm{~m}$ $\times 0.3 \mathrm{~m}$; at site 17 , the basin was $50.5 \mathrm{~m} \times 3 \mathrm{~m}$ $\times 0.3 \mathrm{~m}$; and at site 19 , the basin was $62 \mathrm{~m} \times 3$ $\mathrm{m} \times 0.3 \mathrm{~m}$. Trees were monitored daily during basin tests to determine how rapidly they responded in their $\psi p d$ (an increase of $>0.10$ $\mathrm{MPa}$ ) to the addition of water, and how rapidly they became water stressed again $(<-0.30 \mathrm{MPa}$.).

\section{Data Analyses}

All statistical analyses were performed using SAS@ 9.4 software (SAS Institute, Cary, North Carolina, U.S.). Relationships between percent soil moisture and $\psi$ pd were assessed using Pearson's correlation coefficients, with $P<0.05$ considered significant. Researchers compared percent soil moisture at all depths, at the tubes closest to the canal, and $\psi$ pd taken within 24 hours of the soil moisture reading at that site. The length of time to initial stress was the number of days between the last run of the canal in the spring and the monitoring date when average upd for a site fell to $-0.30 \mathrm{MPa}$ or less. If there was no spring canal run, then the starting date was 15 May. The effect of rainfall events on $\psi p d$ were visually analyzed by plotting the occurrence of every rain event and the following $\psi \mathrm{pd}$ for 2001 through 2008 for sites 8-14. If there was an increase $(>-0.1 \mathrm{MPa})$ in $\psi$ pd after a rain event, it was assumed the rain event affected the water potential. A rain event amount was defined as the cumulative rainfall during one to three consecutive days of rain. The duration of the rain effect on the tree $\psi$ pd was based on the number of weekly readings that were significantly higher (i.e., less stressed) after a rain event. Researchers tested the relationship between $\psi \mathrm{pd}$ and percent crown dieback in autumn of each year, using initial spring (20 May - 10 June), growing season (average of all readings), and autumn (last reading between 15 August - 15 September) $\psi$ pd with Pearson's correlation coefficients. Water potential data and percent crown dieback values were both skewed and therefore square root transformed prior to analyses. Regression modeling did not produce a model that was strong enough to predict crown dieback.

\section{RESULTS}

\section{Canal Water Flow}

Water flow in the canal varied yearly and was regulated by Denver Water (Table 2). Factors affecting water flow in the canal included amounts of mountain snowpack and precipitation during the current year (Don Kennedy, Denver Water, personal communication). Water flowed for over 100 days in some years, but during years of drought, such as in 2002, no water was allocated (Table 2). Waterflow rate influenced the distance that the water traveled in the canal. Water releases with low flow rates did not move water far down the canal, leaving some downstream study sites without water. 
Table 2. Number of days from spring canal runs to moderate (<--0.30 MPa) and severe (<-0.50 MPa) water stress based on predawn leaf water potentials ( $\psi$ pd) of plains cottonwoods within each canal section along the High Line Canal, Denver, Colorado, U.S. (1998-2008). Yearly days and mean over all years are presented. SE = standard error; hyphen (-) = data not collected.

\begin{tabular}{|c|c|c|c|c|c|c|c|c|}
\hline Canal section & Year & Sites (n) & $\begin{array}{l}\text { Days of } \\
\text { canal water }\end{array}$ & $\begin{array}{l}\text { Days to moderate } \\
\text { stress }\end{array}$ & SE & $\begin{array}{l}\text { Sites with severe } \\
\text { stress }(n)\end{array}$ & $\begin{array}{l}\text { Days to } \\
\text { severe stress }\end{array}$ & $\mathrm{SE}$ \\
\hline \multirow[t]{8}{*}{ Cherry Creek } & 1998 & 7 & 79 & 46 & 1.3 & 0 & 0 & \\
\hline & 1999 & 7 & 146 & 60 & 2.9 & 4 & 74 & 0.8 \\
\hline & $2000-2003$ & - & - & - & - & - & - & - \\
\hline & 2004 & 7 & 14 & 22 & 2.9 & 3 & 26 & 5.1 \\
\hline & 2005 & 7 & 50 & 25 & 1.3 & 5 & 48 & 6.5 \\
\hline & 2006 & - & - & - & - & - & - & - \\
\hline & 2007 & 7 & 21 & 14 & 1.5 & 7 & 43 & 3.5 \\
\hline & 2008 & 7 & 21 & - & - & 7 & 23 & 4.6 \\
\hline Mean (all years) & & & & 33.4 & 8.2 & & 42.8 & 8.7 \\
\hline \multirow[t]{11}{*}{ Toll Gate Creek } & 1998 & 2 & 79 & 54. & 10.6 & 1 & 60 & - \\
\hline & 1999 & 5 & 56 & 28 & 4.5 & 2 & 92 & 7.1 \\
\hline & 2000 & 6 & 24 & 74 & 1.6 & 0 & no & - \\
\hline & 2001 & 3 & 64 & 46 & 9.1 & 1 & 81 & - \\
\hline & 2002 & 2 & 0 & 0 & 0 & 2 & 14 & 13.6 \\
\hline & 2003 & 4 & 14 & 50 & 5.4 & 3 & 66 & 5.5 \\
\hline & 2004 & 4 & 0 & 16 & 1.5 & 0 & no & - \\
\hline & 2005 & 4 & 50 & 38 & 1.8 & 2 & 38 & 5.1 \\
\hline & 2006 & - & - & - & - & - & - & - \\
\hline & 2007 & 4 & 14 & 18 & 2.0 & 3 & 60 & 7.8 \\
\hline & 2008 & 4 & 14 & - & - & 2 & 35 & 8.0 \\
\hline Mean (all years) & & & & 40.4 & 7.4 & & 56.0 & 8.8 \\
\hline \multirow[t]{9}{*}{ Sand Creek } & 1998 & 4 & 79 & 56 & 4.5 & 2 & 62 & 2.5 \\
\hline & 1999 & 4 & 56 & 58 & 8.4 & 2 & 92 & 3.7 \\
\hline & 2000 & 6 & 24 & 72 & 3.3 & 4 & 78 & 3.3 \\
\hline & 2001 & 6 & 30 & 46 & 2.4 & 3 & 47 & 6.1 \\
\hline & 2002 & 6 & 0 & 0 & 0 & 6 & 20 & 5.1 \\
\hline & 2003 & 4 & 7 & 36 & 5.8 & 3 & 76 & 29.4 \\
\hline & 2004-2006 & 3 & - & - & - & - & - & - \\
\hline & 2007 & 3 & 0 & 4 & 2.9 & 2 & 18 & 3.5 \\
\hline & 2008 & 3 & 0 & 0 & 0 & 1 & 15 & - \\
\hline Mean (all years) & & & & 45.0 & 8.9 & & 50.9 & 11.1 \\
\hline
\end{tabular}

\section{Question \#1: Can percent soil moisture pre- dict leaf $\psi p d$ ?}

Soil moisture readings in the tubes closest to the canal (one meter from canal) were generally higher $(2 \%-3 \%)$ than from tubes placed 7.6 and $15.2 \mathrm{~m}$ from the canal, so these values were used to represent soil moisture along the canal. Soil moisture at depths influenced by canal flow along the Toll Gate Creek section of the canal averaged $21 \%$ over all sites with a range of $18 \%-32 \%$, while soil moisture at sites on the Sand Creek section, the last section downstream that rarely received canal water, averaged 9.8\%, with a range of $7 \%-12 \%$ (Figure 1 , data not shown).

Significant correlations between percent soil moisture and $\psi$ pd were rare; only $31 \%$ of the pairing at depths where canal water was expected to influence soil moisture were significant (Table 3). Significant correlation coefficients ranged from poor $(r=0.28)$ to moderate $(r=0.83)$. Of the significant correlations, the average correla- tions were $\mathrm{r}=0.46,0.53,0.40$, and 0.39 at depths of $0.9,1.5,2.1$, and $2.7 \mathrm{~m}$, respectively (Table $3)$. Groundwater was deep at the four observation wells. At sites 6 and 17, average groundwater depth was 7.1 and $6.6 \mathrm{~m}$, respectively, and at sites 20 and 2, groundwater depths were always greater than the depth of the observation well $(>9.1 \mathrm{~m})$. During the drought of the summer of 2002, when there was no canal flow or precipitation, groundwater depths at sites 6 and 17 were more than one meter greater than other years (8.5 and $7.9 \mathrm{~m}$ deep) (data not shown).

Root distribution of one large cottonwood tree growing on the canal bank was primarily in the canal bank next to the canal, not extending under the canal or very far from the side of the canal (Figure 2). Mostly small diameter roots were found under the middle of the canal and at the edge of the canal; only a few medium diameter roots were found, along with many small diameter roots. All 
large structural roots $(>2.5 \mathrm{~cm})$ were within the ditch bank within $2.4 \mathrm{~m}$ of the ditch edge, while medium $(0.3-2.5 \mathrm{~cm})$ and small diameter roots $(<0.3 \mathrm{~cm})$ extended away from the canal for $4.2 \mathrm{~m}$ (Figure 2).

\section{Question \#2: How long does it take for trees to become water stressed when water is withheld?}

Cottonwood trees became moderately water stressed ( $\psi \mathrm{pd}<-0.3 \mathrm{MPa}$ ) on average in 45 days (SE $=8.9$, range $=14-74$ days $)$ and severely stressed $(<-$ $0.5 \mathrm{MPa})$ on average in 51 days $(\mathrm{SE}=11.1$, range = 23-92 days) following a two-week long spring canal run and no further water additions to the canal (Table 2). During years in which there was a spring canal run, trees usually became moderately water stressed in early July to early August. Trees were already moderately stressed at Toll Gate Creek and Sand Creek sites at the first water potential ( $\psi p d)$ measurements in the spring (01 June) when there was no spring canal run and winter conditions were dry, as in 2002 (Table 2; Figure 3).

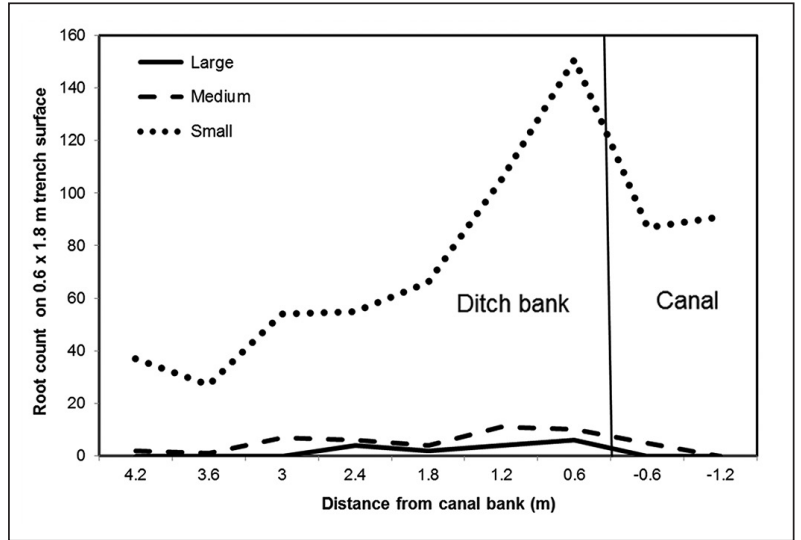

Figure 2. Horizontal root distribution of large $(>2.5 \mathrm{~cm}$ diameter), medium (0.3-2.5 cm diameter) and small $(0.001-0.3 \mathrm{~cm}$ diameter) roots of one plains cottonwood tree $(78 \mathrm{~cm} \mathrm{DBH})$ growing in the bank ( $1 \mathrm{~m}$ from edge of canal) along the Sand Creek canal section of the High Line Canal, Denver, Colorado, U.S., where there was no surrounding urban development. Root counts were recorded on the vertical face of an excavated trench dug perpendicular to the canal. Small absorption roots were concentrated in the ditch bank within $2 \mathrm{~m}$ of the canal. The canal bottom was $1.2 \mathrm{~m}$ deep from the top of the canal bank. Vertical line represents canal bank.

Table 3. Pearson correlation coefficients of percent soil moisture within one meter of canal edge and corresponding cottonwood leaf predawn water potentials ( $\psi$ pd) taken within 24 hours of soil moisture readings in 2001-2003 along the High Line Canal, Denver, Colorado, U.S. Hyphen $(-)=$ data not collected; bold $=$ depth where canal flow was assumed to influence soil moisture (see Methods section for details); asterisk ( ${ }^{*}$ ) = significant at $P<0.05$.

\begin{tabular}{|c|c|c|c|c|c|c|c|}
\hline \multirow[t]{2}{*}{ Canal section } & \multirow[t]{2}{*}{ Year } & \multirow[t]{2}{*}{ Site } & \multicolumn{5}{|l|}{ Depth } \\
\hline & & & $0.3 \mathrm{~m}$ & $0.9 \mathrm{~m}$ & $1.5 \mathrm{~m}$ & $2.1 \mathrm{~m}$ & $2.7 \mathrm{~m}$ \\
\hline \multirow[t]{5}{*}{ Sand Creek } & 2001 & 2 & 0.13 & $0.51^{\star}$ & $0.63^{*}$ & $0.39^{\star}$ & 0.23 \\
\hline & & 16 & 0.15 & 0.19 & 0.09 & 0.08 & 0.06 \\
\hline & & 23 & $0.41^{\star}$ & $0.48^{\star}$ & $0.58^{\star}$ & $0.46^{*}$ & $0.42^{\star}$ \\
\hline & & 25 & $0.54^{*}$ & $0.63^{\star}$ & $0.83^{*}$ & 0.18 & 0.16 \\
\hline & & 17 & 0.22 & $0.41^{\star}$ & $0.52^{\star}$ & 0.19 & 0.21 \\
\hline \multirow[t]{3}{*}{ Toll Gate Creek } & 2001 & 6 & 0.09 & $0.39^{*}$ & 0.29 & 0.18 & 0.16 \\
\hline & & 19 & - & - & - & - & - \\
\hline & & 20 & 0.22 & 0.24 & $0.39^{*}$ & 0.32 & 0.20 \\
\hline \multirow[t]{5}{*}{ Sand Creek } & 2002 & 2 & 0.09 & 0.17 & 0.07 & 0.08 & 0.19 \\
\hline & & 16 & $0.37^{\star}$ & 0.16 & 0.04 & 0.06 & 0.03 \\
\hline & & 23 & $0.47^{\star}$ & 0.08 & 0.09 & 0.09 & 0.11 \\
\hline & & 25 & $0.43^{*}$ & 0.03 & 0.24 & 0.10 & 0.01 \\
\hline & & 17 & 0.05 & 0.10 & 0.25 & 0.08 & 0.11 \\
\hline \multirow[t]{3}{*}{ Toll Gate Creek } & 2002 & 6 & $0.34^{*}$ & $0.34^{\star}$ & 0.10 & 0.19 & $0.28^{*}$ \\
\hline & & 19 & 0.01 & 0.01 & 0.03 & 0.04 & 0.08 \\
\hline & & 20 & $0.59^{*}$ & 0.16 & $0.32^{*}$ & $0.36^{*}$ & $0.45^{\star}$ \\
\hline \multirow[t]{5}{*}{ Sand Creek } & 2003 & 2 & 0.01 & 0.07 & 0.01 & 0.06 & 0.15 \\
\hline & & 16 & 0.04 & 0.06 & 0.01 & 0.02 & 0.06 \\
\hline & & 23 & 0.12 & 0.09 & 0.11 & 0.03 & 0.02 \\
\hline & & 25 & 0.06 & 0.37 & $0.55^{\star}$ & $0.46^{*}$ & 0.06 \\
\hline & & 17 & 0.26 & 0.19 & 0.14 & 0.41 & 0.07 \\
\hline \multirow[t]{3}{*}{ Toll Gate Creek } & 2003 & 6 & 0.15 & 0.21 & 0.16 & 0.03 & 0.17 \\
\hline & & 19 & 0.29 & $0.31^{\star}$ & $0.45^{\star}$ & $0.34^{\star}$ & $0.40^{*}$ \\
\hline & & 20 & 0.11 & 0.16 & 0.23 & 0.10 & 0.04 \\
\hline
\end{tabular}




\section{Question \#3: How rapidly do moderately to severely stressed trees recover after water is provided?}

After the addition of water to the canal, waterstressed cottonwood trees responded by increasing upd by at least $0.10 \mathrm{MPa}$ within two days, on average, over two years of measurements (range $=1-3$ days) (Table 4 ). The number of days after water was added until the highest upd (least negative number) was reached averaged 5.8 days (range $=3-9$ days) (Table 4 ). The time it took for trees to become moderately water stressed $(<-0.30 \mathrm{MPa})$ again after the water was provided and then withheld was 20.6 days on average (range $=8-36$ days) (Table 4).

\section{Question \#4: Do summer precipitation events reduce water stress?}

Significant rain events of at least $25 \mathrm{~mm}$ were needed to provide enough soil water to relieve water stress (defined as an increase of $0.1 \mathrm{MPa}$ in upd). The occurrence of $25 \mathrm{~mm}$ rain events was rare with only one to six events per growing season noted over eight years (Table 5). On average, $22 \%$ of the sites had trees that responded to the 16 significant rain events that occurred in 20012008 , but trees at $67 \%$ of sites responded during the driest year, 2002 (Table 5). The longest duration of water-stress relief (maintenance of high upd), at any of the sites, was seven days (Table 5).

\section{Question \#5: Can predawn tree water poten- tials predict future crown dieback?}

Crown dieback in autumn was positively correlated with the average yearly autumn $\psi \mathrm{pd}$ $(\mathrm{r}=0.78, P=0.07)$ and growing season $\psi \mathrm{pd}$ $(\mathrm{r}=0.75, P=0.08)$ in the Sand Creek section (Figure 3C, Sand Creek section). Spring leaf $\psi$ pd did not correlate with autumn crown dieback on the Sand Creek section (data not shown). There were no significant correlations between tree or site averages of yearly spring, growing season, and autumn ( $\psi \mathrm{pd})$, and autumn crown dieback along the Cherry Creek and Toll Gate Creek sections. Trees in the Toll Gate Creek section experienced low $\psi$ pd (moderate to severe water stress) during the 2002 drought but autumn crown dieback did not continually increase over time and few trees died as a result (Figure 3B). The background amount of crown dieback on the average cottonwood along the canal in no-stress sites (most canal-flow days) was $10 \%-15 \%$ (Figure $3 \mathrm{~A}$ ).

Comparing tree response at three representative sites that experienced no stress (site 20, $28.5 \%$ average soil moisture at all soil depths over all years, $\mathrm{SE} \pm 0.3$ ), moderate stress (site $6,13.2 \%$ average soil moisture, $\mathrm{SE} \pm 0.2$ ), or severe stress (site 2, 9.7\% average soil moisture, $\mathrm{SE} \pm 0.1$ ) provided an additional illustration of the response of plains cottonwoods to prolonged below-normal soil moisture conditions (Figures 4A; Figure 4B; Figure 4C). Trees at the no-stress site had no crown dieback because upd was maintained between -0.1 and $-0.3 \mathrm{MPa}$ in all years, except for 2002 and 2007 (Figure 4A). Average spring, summer, and autumn $\psi$ pd were $-0.19 \pm 0.02 \mathrm{SE},-0.25 \pm 0.01$, and $-0.29 \pm$ $0.01 \mathrm{MPa}$, respectively, over all years. Although average autumn $\psi$ pd fell to $-0.46 \mathrm{MPa}$ during the 2002 drought, crown dieback did not occur that year or in subsequent years (Figure 4A).

Percent crown dieback of trees at the moderate-stress site increased after the 2002 drought (Figure 4B). Trees averaged 25\% dieback over the study period with a maximum dieback of $40 \%$ on a few trees the year after the 2002 drought. Pre-

Table 4. Mean predawn leaf water potentials ( $\psi \mathrm{pd}$ ) and number of days to different levels of $\psi$ pd increases of plains cottonwood trees at three study sites over two years after the addition of water to the canal ${ }^{2}$ along the High Line Canal, Denver, Colorado, U.S. (2002-2003). SE = standard error.

\begin{tabular}{|c|c|c|c|c|c|c|c|c|}
\hline Year & Site & Trees & $\begin{array}{l}\text { Days of } \\
\text { water }^{z}\end{array}$ & $\begin{array}{l}\text { Mean water potential (MPa) } \\
\text { before water added }(\mathrm{SE})\end{array}$ & $\begin{array}{l}\text { Mean water potential }(\mathrm{MPa}) \\
\text { after water added }(\mathrm{SE})\end{array}$ & $\begin{array}{l}\text { Days to } \\
>-0.10 \mathrm{MPa}\end{array}$ & $\begin{array}{l}\text { Days to highest } \\
\text { water potential }\end{array}$ & $\begin{array}{l}\text { Days to decrease } \\
\text { back to }<-0.30 \mathrm{MPa}\end{array}$ \\
\hline \multirow[t]{2}{*}{2002} & 2 & 5 & 4 & $-0.67(-0.13)$ & $-0.38(-0.07)$ & 1 & 7 & 8 \\
\hline & 19 & 3 & 4 & $-1.00(-0.23)$ & $-0.55(-0.11)$ & 1 & 9 & 14 \\
\hline \multirow[t]{3}{*}{2003} & 2 & 5 & 10 & $-0.40(-0.08)$ & $-0.25(-0.03)$ & 3 & 5 & 36 \\
\hline & 17 & 3 & 10 & $-0.31(-0.07)$ & $-0.22(-0.04)$ & 3 & 5 & 28 \\
\hline & 6 & 5 & 4 & $-0.38(-0.06$ & $-0.27(-0.04)$ & 2 & 3 & 17 \\
\hline Mean & & & & $-0.55(-0.11)$ & $-0.33(-0.06)$ & 2 & 5.8 & 20.6 \\
\hline
\end{tabular}

${ }^{\mathrm{z}}$ Water source for basin in canal was a water truck or fire hydrant. 
Table 5. Percent of sites with substantial' increases in predawn leaf water potentials ( $\psi$ pd) of plains cottonwood trees along the High Line Canal, Denver, Colorado, U.S., after large precipitation eventsy, 2001-2008x, NOAA, Meteorological Station, Denver Stapleton, \#0522220.

\begin{tabular}{|c|c|c|c|c|}
\hline Year & $\begin{array}{l}\text { Number of } \\
\text { sites }\end{array}$ & $\begin{array}{l}\text { Precip events } \\
>25 \mathrm{~mm}^{\mathrm{y}}\end{array}$ & $\begin{array}{l}\text { Percent of events } \\
\text { with substantial } \psi \mathrm{pd} \\
\text { increase }^{\mathrm{z}}(\%)\end{array}$ & $\begin{array}{l}\text { Duration of water } \\
\text { potential increase } \\
\text { (days) }\end{array}$ \\
\hline 2001 & 8 & 6 & 27 & 7 \\
\hline 2002 & 9 & 1 & 67 & $\mathrm{n} / \mathrm{a}^{\mathrm{w}}$ \\
\hline 2003 & 13 & 2 & 4 & 7 \\
\hline 2004 & 12 & 1 & 0 & - \\
\hline 2005 & 12 & 1 & 42 & 7 \\
\hline 2006 & 14 & 3 & 36 & 7 \\
\hline 2007 & 13 & 1 & 0 & - \\
\hline 2008 & 14 & 2 & 0 & - \\
\hline
\end{tabular}

${ }^{z} \psi$ pd were increased $(>0.10 \mathrm{MPa})$ after reaching at least $-0.30 \mathrm{MPa}$.

y Precipitation events that increased $\psi$ pd by $0.1 \mathrm{MPA}$ were only those greater than $25 \mathrm{~mm}$.

${ }^{x}$ Data on precipitation and corresponding $\psi$ pd not available for 1998-2000.

${ }^{\mathrm{w}}$ upd data were not available.

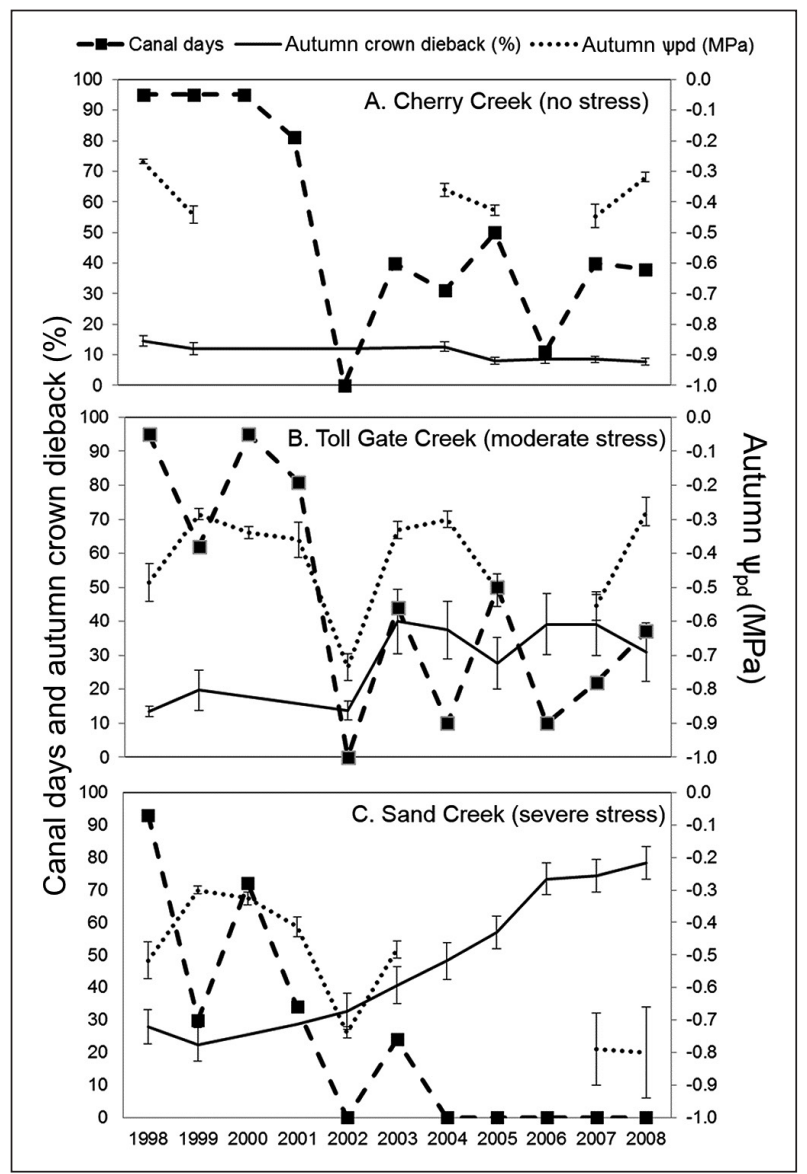

Figure 3. Days of canal flow and yearly means (+/- one standard error) of percent autumn crown dieback and autumn predawn leaf water potentials ( $\psi \mathrm{pd})(\mathrm{MPa})$ of plains cottonwood trees on the A) Cherry Creek ( $n=8$ sites), B) Toll Gate Creek ( $n=6$ sites), and C) Sand Creek ( $n=9$ sites) canal sections, High Line Canal, Denver, Colorado (1998-2008). Sites represent various levels of water stress based on number of canal-flow days (no, moderate, and severe stress, respectively). Missing sections indicate no data collected

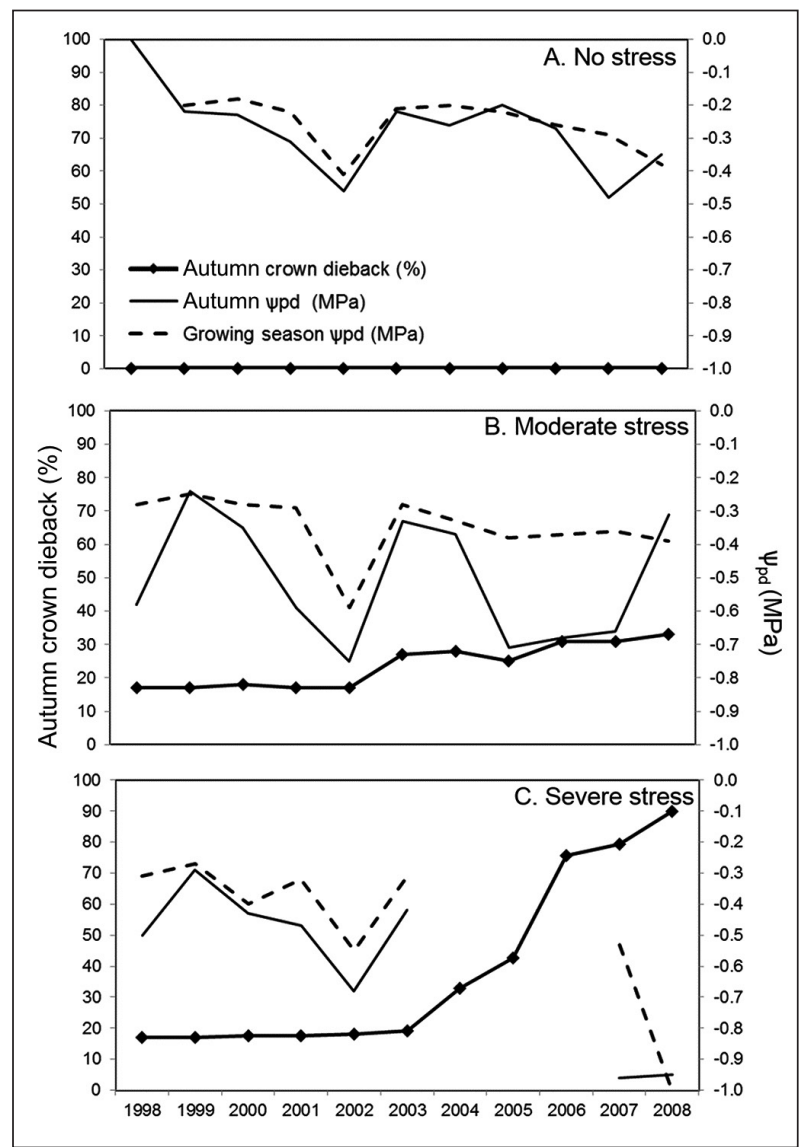

Figure 4. Yearly mean percent autumn crown dieback, autumn predawn water potentials $(\psi \mathrm{pd})(\mathrm{MPa})$, and growing season $\psi$ pd for plains cottonwoods growing along the High Line Canal, Denver, Colorado (1998-2008) at three representative sites that represent $A$ ) no stress (site $20, n=3$ trees), B) moderate stress (site 6, $n=5$ trees), and C) severe stress (site 2, $\mathrm{n}=7$ trees). 
dawn leaf $\psi$ in 2002 dropped below $-0.5 \mathrm{MPa}$ for both growing season and autumn $\psi$ pd, but these low values were not sustained through subsequent years, so crown dieback did not increase. Average spring, summer, and autumn $\psi \mathrm{pd}$ were $-0.21 \pm 0.015$ SE, $-0.35 \pm 0.01$, and $-0.49 \pm 0.03$ $\mathrm{MPa}$, respectively. Trees at the severe-stress site increased in crown dieback starting in 2003, and most trees were dead by 2008 (Figure 4C). After 2003, canal flow ended (Figure 4C), and percent crown dieback increased every year because water stress was never relieved (Figure $4 \mathrm{C}$ ). Average spring, summer, and autumn predawn $\psi$ pd were $-0.26 \pm 0.03 \mathrm{SE},-0.41 \pm$ 0.03 , and $-0.56 \pm 0.03 \mathrm{MPa}$, respectively, over all years of available data. During the last two years of data, when most trees had died or were dying, the average summer $\psi \mathrm{pd}$ were $-0.53 \pm$ $0.04 \mathrm{MPa}$ in 2007 and $-1.04 \pm 0.05 \mathrm{MPa}$ in 2008 .

\section{DISCUSSION}

Percent soil moisture did not relate well with cottonwood water status ( $\psi \mathrm{pd}$ ) in this study. Predawn leaf $\psi \mathrm{pd}$ is often used to represent the equilibrium between the non-transpiring plant and available soil moisture, but often these two variables have wide discrepancies (disequilibrium), especially in well-watered soils (Sellin 1999; Donovan et al. 2001). Native plains cottonwoods growing where the groundwater depth was less than $3 \mathrm{~m}$ had weak to moderate relationships between soil moisture content and $\psi$ pd in a study along Colorado rivers during experimental flooding (Williams and Cooper 2005). Groundwater depth in the current study averaged $>7 \mathrm{~m}$, and soil moisture monitoring only measured down to $3.7 \mathrm{~m}$, which may have contributed to weak relationships between soil moisture and tree upd along the HLC. Researchers do not recommend the expense and complexity of monitoring soil moisture to assess the water status of canal-side or urban trees. It was more direct and easier to obtain $\psi$ pd than to drill holes, install soil access tubes, and use a soilmoisture gauge. The neutron probe gauge used in this study required radioactive exposure monitoring and reporting, tasks most land managers and professionals may not want to be burdened with.

The time it took for plains cottonwood trees to become water-stressed, when water was with- held from the canal, depended on the presence and frequency of canal flow in spring and most likely the quantity of the soil moisture reservoir. When water was provided in the spring for several weeks and then the canal flow ended, it took approximately 45 and 51 days on average for trees to reach moderate stress $(\psi \mathrm{pd}<-0.30 \mathrm{MPa}$ ) or severe stress ( $\psi \mathrm{pd}<-0.50 \mathrm{MPa})$, respectively. These data indicate that plains cottonwoods can survive severe droughts (as in 2002) if there is a minimum of 14 days of soil saturation during the growing season in following years (Table 2). The plains cottonwoods along the HLC apparently have different amounts of soil moisture reservoirs to draw on after canal flow ends, because some trees exhibited immediate water stress, and some trees took three months to exhibit severe water stress (range $=23$ to 92 days) (Table 2). Other species of cottonwoods are also sensitive to water stress and show similar levels of dieback and mortality within two weeks to a few years (Scott et al. 1999; Cooper et al. 2003; Coble and Kolb 2012), as witnessed along the Sand Creek section of the canal where most trees died (Figure 3C; Figure 4C). Severe crown dieback tends to occur the year water is halted (i.e., by pumping or mining activities) and mortality of trees occurs within two to three years (Scott et al. 1999; Cooper et al. 2003; Coble and Kolb 2012).

Water-stressed cottonwood trees increased their upd after a short-term addition of water was provided within 24 to 72 hours, and remained less stressed for 8 to 36 days. The relatively rapid response of trees to the addition of water to the soil profile was because the trees roots were still alive and able to uptake the water placed in the canal. This conforms with data that illustrated plains cottonwoods maintained high $\psi$ pd during water table dry-downs in hot, mid-summer temperatures because of short-duration peaks in river flow (Cooper et al. 2003), in contrast, others have noted no physiological responses after the addition of water to soil surfaces (Cox et al. 2005; Williams and Cooper 2005). At sites where experimental flooding of soil surfaces occurred, a previous loss of shallow roots due to the long-term (several years) regulated flow regime of the river was noted (Williams and Cooper 2005). Thus, the water experimentally added to the soil surface 
could not be acquired by the trees due to the loss of functional shallow roots (Williams and Cooper 2005). In the current study, the water additions occurred in July and August, following low to no spring season canal-flow days, and so water addition is recommend at or before this time, during the growing period in similar climates.

Summer precipitation events providing at least 25 $\mathrm{mm}$ of water can improve the water status ( $\psi \mathrm{pd}$ ) of cottonwood trees for up to one week, but researchers do not recommend relying on summer rain events to maintain plains cottonwood tree health in semi-arid urban areas. The soil moisture relief was short-lived, precipitation events of this magnitude were infrequent, and the positive impact on trees was rare. Trees will need to be irrigated during prolonged periods without precipitation.

Cottonwood trees are vulnerable to water stress-induced xylem dysfunction due to cavitation, which can lead to the death of leaves and branches, and crown dieback (Tyree et al. 1994; Cooper et al. 2003; Fichot et al. 2015). Predawn leaf water potential ( $\psi \mathrm{pd}$ ) measures the overall water status when transpiration ends following soil re-saturation (i.e., the minimum water stress, or recovery period), whereas $\psi \mathrm{md}$ measure the maximum water stress during the most stressful time of the day during transpiration (Jones 1990; Cooper et al. 2003). Researchers used upd as a measure of tree water status instead of $\psi$ md because of the great variation of the current study's preliminary daytime readings ( $\psi \mathrm{md}$, collected in 1999 only), most likely caused by the influence air temperature and cloud cover/ irradiation (data not shown) (Jones 1990; Fichot et al. 2015). This subset of $\psi \mathrm{md}$ commonly ranged from - 1.0 to $-2.3 \mathrm{MPa}$ with no branch dieback in that year or in following years. Researchers observed $\psi$ pd readings to be reproducible over time, and thus opted to use the more conservative predawn water potentials in this study.

Leaf and branch sacrifice and exogenous water sources may allow severely stressed trees, such as those in the current study, which had autumn upd of $<-0.5 \mathrm{MPa}$, to survive as has been noted in previous research (Rood et al. 2003; Williams and Cooper 2005). The low upd researchers observed and measured would need to occur for several years in a row for eventual mortality to follow. However, branch dieback can be predicted to occur within the ranges found here and from other studies on cottonwood species. Predawn leaf upd values measured in this study fall in the same range as other cottonwood species associated with dieback in Colorado (-0.3 to -0.8 MPa) (Cooper et al. 2003; Williams and Cooper 2005) and in Arizona on Fremont cottonwood (Populus deltoides subsp wislizenii) (Horton et al. 2001). Because upd should be considered a minimum stress level, compared to midday water potentials ( $\psi \mathrm{md}$, maximum stress), $\psi$ pd values measured along the HLC in Denver, Colorado, were well above $\psi$ md reported to cause the needed $80 \%-100 \%$ cavitation for mortality to occur in other cottonwood species (-1.7 to -2.5 MPa) (Tyree et al. 1994; Leffler et al. 2000; Schreiber et al. 2011; Fichot et al. 2015).

Several notable findings occurred in this study related to $\psi \mathrm{pd}$ and cottonwood tree health that can provide tree health care professionals with some predictive power for future branch dieback when they measure $\psi \mathrm{pd}$. Tree responses to fluctuating soil moisture conditions were observed over 10 years, and the findings included that plains cottonwoods along the HLC are relatively resilient to a single-year drought. Trees that maintained predawn $\psi$ pd above $-0.30 \mathrm{MPa}$ did not incur leaf or branch dieback, whereas trees that had autumn or growing season average upd values below $-0.50 \mathrm{MPa}$ exhibited branch dieback. Moderately stressed trees may recover the following year and can withstand considerable crown dieback $(25 \%-40 \%)$ if sufficient water is available the following year(s).

\section{CONCLUSIONS AND MANAGE- MENT RECOMMENDATIONS}

Based on the findings related to $\psi \mathrm{pd}$, researchers suggest the following simple management actions for monitoring the water status of plains cottonwoods:

- Obtain upd readings once a month during periods of below-normal precipitation or reduced availability of irrigation water.

- Provide enough water to saturate the root zone when $\psi \mathrm{pd}$ of -0.3 to $-0.5 \mathrm{MPa}$ are recorded to reduce crown dieback.

- If the site monitor can only visit trees once a year, $\psi$ pd readings and corresponding crown 
dieback taken in the last week of August to the second week of September are sufficient to monitor the water status and future health of cottonwoods in Front Range Colorado.

- If spring water (May-June) is provided and then supplemental water is provided again in July or August (because cottonwood trees become moderately water-stressed in one to two months after water is provided in the spring), trees can be expected to survive.

Other key findings important to maintaining healthy cottonwood trees in urban environments:

- Summer precipitation should not be relied upon to relieve water stress for longer than one week in cottonwoods.

- Soil moisture readings are not easy to obtain, nor are they good proxies of the predawn water status of cottonwoods.

- Providing additional water to the root zones of cottonwood trees during periods of below-normal precipitation can minimize crown dieback.

Acknowledgments. We would like to thank the following individuals for their contributions: L. Van Alyne, H.O. Jacobi, E.F. Jacobi, C.B. Preston for technical assistance, G.E. Cardon and D. Cooper for water and soil-moisture advice, J. zumBrunnen and P. Turk for statistical assistance (Colorado State University, Franklin A. Graybill Statistical Laboratory), M. Bowers, J. Foster, D. Kennedy, J. Loran, G. Martinez, and T. Mulligan for funding, and technical and logistical support at Denver Water. This study was funded by Denver Water and Colorado State University, Agricultural Experiment Station.

\section{LITERATURE CITED}

Amlin, N.M., and S.B. Rood. 2003. Drought stress and recovery of riparian cottonwoods due to water table alteration along Willow Creek, Alberta. Trees 17:351-358.

Coble, A.P., and T.E Kolb. 2012. Riparian tree growth response to drought and altered streamflow along the Dolores River, Colorado. Western Journal of Applied Forestry 27:205-211.

Cooper, D.J., D.R. D’Amico, and M.L. Scott. 2003. Physiological and morphological response patterns of Populus deltoides to alluvial groundwater pumping. Environmental Management $31: 215-226$.

Cox, G., D. Fisher, S.C. Hart, and T.G Whitham. 2005. Nonresponse of native cottonwood trees to water additions during summer drought. Western North American Naturalist 65:175-185.

Donovan, L., M. Linton, and J. Richards. 2001. Predawn plant water potential does not necessarily equilibrate with soil water potential under well-watered conditions. Oecologia 129:328-335.

Fichot, R., F. Brignolas, H. Cochard, and R. Ceulemans. 2015. Vulnerability to drought-induced cavitation in poplars: Syn- thesis and future opportunities. Plant, Cell, and Environment 38:1233-1251

Horton, J.L., S.C. Hart, and T.E Kolb. 2003. Physiological condition and water source use of Sonoran desert riparian trees at the Bill Williams River, Arizona, USA. Isotopes Environmental Health Studies 39:69-82.

Horton, J.L., T.E. Kolb, and S.C. Hart. 2001. Responses of riparian trees to interannual variation in ground water depth in a semiarid river basin. Plant, Cell, and Environment 24:293-304.

Jones, H.G. 1990. Physiological aspects of the control of water status in horticultural crops. HortScience 25:19-26.

Kramer, P.J., and T.T. Kozlowski. 1979. Physiology of Woody Plants. Academic Press, Cambridge, Massachusetts, U.S. 811 pp.

Leffler, A.J., L.E. England, and J. Naito. 2000. Vulnerability of Fremont cottonwood (Populus fremontii Wats.) individuals to xylem cavitation. Western North American Naturalist 60:204-210.

Rood, S.B., and J.M. Mahoney.1995. River damming and riparian cottonwoods along the Marias River, Montana. Rivers 5:195-207.

Rood, S.B., J.H. Braatne, and F.M.R. Hughes. 2003. Ecophysiology of riparian cottonwoods: Stream flow dependency, water relations and restoration. Tree Physiology 23:1113-1124.

Schulte, P.J., T.M. Hinckley, and R.F. Stettler. 1987. Stomatal responses of Populus to leaf water potential. Canadian Journal of Botany 65:255-260.

Scott, M.L., P.B. Shafroth, and G.T. Auble. 1999. Responses of riparian cottonwoods to alluvial water table declines. Environmental Management 23:347-358.

Sellin, A. 1999. Does pre-dawn water potential reflect conditions of equilibrium in plant and soil water status? Acta Oecol 20:51-59.

Skari, D. 2003. High Line Canal Meandering Through Time. C \& M Press, Denver, Colorado, U.S. 158 pp.

Tyree, M.T., K.J. Kolb, S.B. Rood, and S. Patiño. 1994. Vulnerability to drought-induced cavitation of riparian cottonwoods in Alberta: A possible factor in the decline of the ecosystem? Tree Physiology 14:455-466.

Williams, C.A., and D.J Cooper. 2005. Mechanisms of riparian cottonwood decline along regulated rivers. Ecosystems 8:382-395.

Williams, L.E., and F.J. Araujo. 2002. Correlations among predawn leaf, midday leaf, and midday stem water potential and their correlations with other measures of soil and plant water status in Vitis vinifera. Journal of the American Society for Horticultural Science 127:448-454.

William R. Jacobi (corresponding author)

Department of Bioagricultural Sciences and Pest Management Colorado State University

Fort Collins, Colorado 80523, U.S.

william.Jacobi@colostate.edu

Ronda D. Koski

Department of Horticulture and Landscape Architecture

Colorado State University

Fort Collins, Colorado 80523, U.S.

Betsy A. Goodrich

USDA Forest Service, Forest Health Protection,

Wenatchee Insect and Disease Service Center

Okanogan-Wenatchee NF

1133 N. Western Ave

Wenatchee, Washington 98001, U.S. 
Résumé. Les peupliers deltoïdes des plaines (Populus deltoides subsp. monilifera (Aiton) Eckenw.) se retrouvent dans les zones riveraines et urbaines des régions semi-arides de l'ouest des États-Unis. Le volume d'eau nécessaire pour maintenir ces arbres en bonne santé tout en réduisant l'utilisation de l'eau sont des objectifs de gestion préoccupants le long du canal High Line à Denver, au Colorado, États-Unis. L'écoulement journalier de l'eau du canal, l'humidité du sol, les précipitations, le potentiel hydrique des feuilles de peuplier avant l'aube ( $\psi$ pd) et le dépérissement du houppier ont été mesurés annuellement de 1997 à 2008. Cinq résultats clés furent constatés : 1) aucune corrélation entre l'humidité du sol et le $\psi \mathrm{pd}, 2)$ les arbres devinrent modérément stressés ( $\psi \mathrm{pd}<-0,3 \mathrm{MPa}$ ) et sévèrement stressés par le manque d'eau $(<-0,5 \mathrm{MPa})$ respectivement 45 et 51 jours après la fin de l'écoulement de l'eau du canal, 3) le $\psi$ pd des arbres stressés sur le plan hydrique a augmenté 24 à 48 heures après leur réapprovisionnement en eau, 4) seules $22 \%$ des précipitations de pluie de $25 \mathrm{~mm}$ atténuèrent les conditions de stress pendant sept jours, et 5) la moyenne annuelle du $\psi$ pd durant l'automne et la saison de croissance montrait une corrélation avec le dépérissement automnal du houppier sur les sites caractérisés par une faible humidité du sol (rares jours d'écoulement du canal), mais rien de similaire sur les sites modérés ou élevés (fréquents jours d'écoulement d'eau du canal). Les arbres avec un $\psi \mathrm{pd}>-0.30 \mathrm{MPa}$ montraient un faible taux de dépérissement du houppier, tandis que les arbres avec un $\psi$ pd $<-0.50 \mathrm{MPa}$ présentaient un dépérissement du houppier modéré ou sévère. Les peupliers deltoïdes des plaines sont relativement résistants à une sécheresse annuelle et les arbres modérément stressés peuvent se rétablir et supporter un dépérissement du houppier de 25 à $40 \%$ si l'eau est disponible l'année suivante pendant plus de 14 jours. Le moment approprié pour l'irrigation et sa fréquence, requises afin de minimiser le dépérissement éventuel du houppier des peupliers, peuvent être obtenus à partir de la lecture des potentiels hydriques avant l'aube dans les feuilles à l'automne et en saison de croissance.

Zusammenfassung. Die Pappelart Populus deltoides subsp. monilifera (Aiton) Eckenw. kommt in den Randbereichen und urbanen Arealen in den semi-ariden Regionen der westlichen Vereinigten Staaten vor. Die Wassermenge, die zur Erhaltung von gesunden Bäumen entlang des High Line Canal in Denver, Colorado, U.S erforderlich ist, während der Wasserverbrauch reduziert wird, sind die herausragenden Management Zielobjekte. KanalFließ-Tage, Bodenfeuchte, Niederschlag und das Wasserpotential von Pappelblättern vor dem Morgengrauen ( $\psi \mathrm{pd}$ ) und Kronenabsterben wurde jährlich im Zeitraum von 1997-2008 gemessen. Es gab fünf Schlüsselerkenntnisse: 1. der Prozentsatz an Bodenfeuchte korrelierte nicht mit $\psi \mathrm{pd} ; 2$. die Bäume erlitten mittelmäßigen Wasserstress ( $\psi \mathrm{pd}<-0.3 \mathrm{MPa}$ ) und großen Wasserstress $(<-0.5 \mathrm{MPa})$, bzw. 45 und 51 Tage, nachdem der Wasserfluss aus dem Kanal endete; 3. der $\psi$ pd von Wasser-gestressten Bäumen stieg 24-48 Stunden, nachdem Wasser zugeführt wurde; 4 . nur $22 \%$ der Regenfälle mit $25 \mathrm{~mm}$ konnte den Wasserstress für sieben Tage mindern und 5. der jährliche durchschnittliche Herbst und Vegetationsperioden- $\psi$ pd korrelierte mit dem herbstlichen Kronenrücksterben auf Standorten mit niedriger Bodenfeuchte (wenige Kanal-FließTage), aber nicht an mittleren oder hohen Standorten (mehr KanalFließ-Tage). Bäume mit generell $\psi$ pd $>-0.30 \mathrm{MPa}$ hatten wenig Kronenrücksterben, während Bäume mit $\psi$ pd $<-0.50 \mathrm{MPa}$ zeigten mittleres oder starkes Kronenrücksterben. Delta-Pappeln sind relativ widerstandsfähig bei einen Trockenjahr und mittelstark gestresste können sich erholen und können ein Kronenrücksterben von $35-40 \%$ überleben, wenn im folgenden Jahr das Wasser $>14$ Tage zu Verfügung steht. Die Bewässerungszeiten und die erforderliche Frequenz zur Minimierung eines Kronenrücksterbens von Delta-
Pappeln in der Zukunft können während dem Herbst und der Vegetationszeit aus dem Blattwasserpotential vor dem Morgengrauen geschöpft werden.

Resumen. En las zonas semiáridas del oeste de los Estados Unidos se encuentran árboles de chopo (Populus deltoides subsp. monilifera (Aiton) Eckenw.) en zonas de ripio y en áreas urbanas. La cantidad de agua necesaria para mantener los árboles sanos y reducir el consumo de agua son objetivos de manejo a lo largo del Canal de Línea de Alta en Denver, Colorado, EE.UU. Se midieron anualmente los días de flujo del Canal, humedad del suelo, precipitación entre 1997 y 2008. Los resultados obtenidos fueron: 1) el porcentaje de humedad del suelo no se correlacionó con $\psi$ pd, 2) los árboles estuvieron moderadamente estresados por agua ( $\psi \mathrm{pd}<-0,3 \mathrm{MPa}$ ) y severamente estresados (<-0,5 MPa) 45 y 51 días después de que el flujo del canal terminó, 3) భpd de árboles con estrés hídrico aumentó 24-48 horas después que el agua fue agregada, 4) sólo el 22\% de los eventos de lluvia de $25 \mathrm{~mm}$ aliviaron las condiciones de estrés durante siete días y 5) el promedio anual en otoño y la temporada de crecimiento estuvieron correlacionados con $\psi$ pd con muerte regresiva de otoño en sitios de baja humedad del suelo (pocos días de flujo de canal), pero no en sitios moderados o altos (más días de flujo de canal). Los árboles con $\psi$ pd $>-0.30 \mathrm{MPa}$ generalmente presentaban una degradación baja de la copa, mientras que los árboles con upd <-0.50 MPa presentaban una degradación de copa moderada o severa. Los álamos de las llanuras son relativamente resistentes a la sequía de un año, y los árboles moderadamente estresados pueden recuperarse y pueden soportar una desintegración de la copa entre el $25 \%$ y el $40 \%$ si hay agua disponible el año siguiente durante> 14 días. La temporización del riego y la frecuencia necesaria para minimizar la futura degradación de la copa del álamo se pueden obtener a partir de los potenciales de otoño y de la temporada de crecimiento. 